\title{
Dewey, Economic Democracy, and the Mondragon Cooperatives
}

\author{
Kenneth W. Stikkers
}

\section{CpenEdition}

Journals

Electronic version

URL: http://journals.openedition.org/ejpap/833

DOI: $10.4000 /$ ejpap.833

ISSN: 2036-4091

Publisher

Associazione Pragma

\section{Electronic reference}

Kenneth W. Stikkers, "Dewey, Economic Democracy, and the Mondragon Cooperatives », European Journal of Pragmatism and American Philosophy [Online], III-2 | 2011, Online since 29 December 2011 connection on 19 April 2019. URL : http://journals.openedition.org/ejpap/833 ; DOI : 10.4000/ ejpap.833

This text was automatically generated on 19 April 2019

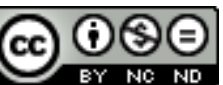

Author retains copyright and grants the European Journal of Pragmatism and American Philosophy right of first publication with the work simultaneously licensed under a Creative Commons AttributionNonCommercial-NoDerivatives 4.0 International License. 


\title{
Dewey, Economic Democracy, and the Mondragon Cooperatives
}

\author{
Kenneth W. Stikkers
}

1 John Dewey, it is well known, believed that any deep and meaningful democracy must be more than a merely formal, procedural one, more than just the occasional casting of "one person, one vote": it must be "a way of life" that entails habits of participation in the governance of the institutions that affect people's lives, proportional to their abilities and interests. Moreover, he did not consider "democracy," in his sense, to be an ideological notion: democracy is but the application of the method of experimental scientific inquiry to social life and, as such, synonymous with healthy, thriving community. Indeed, by his broad definition, Dewey counted flourishing families as "democratic" (Dewey 1927: 325-30). ${ }^{1}$ According to such a notion, though, democracy in the United States is thin and superficial, and the United States' boastful claims to being a beacon of democracy to the world ring hollow and contrast starkly to the authoritarian structures that dominate everyday economic life in the United States and to the plutocratic control of United States political institutions. Indeed, in Individualism old and New Dewey notes the sharp contrast between the United States' professed values of democracy, individualism, and liberty and the reality of autocratic corporate governance:

Most of those who are engaged in the outward work of production and distribution of economic commodities have no share - imaginative, intellectual, emotional - in directing the activities in which they physically participate. [...] economic associations are fixed in ways which exclude most of the workers in them from taking part in their management. The subordination of the enterprise to pecuniary profit reacts to make the workers "hands" only. Their hearts and brains are not engaged. They execute plans which they do not form and of whose meaning and intent - beyond the fact that these plans make a profit for others and secure a wage for themselves. (Dewey 1930: 104)

Democracy in the United States runs shallow and is not a feature of everyday economic life.

What might an economy manifesting Deweyan democratic principles look like? While there have been some interesting applications of Dewey's pragmatism to methodological 
issues of economy (e.g., Khalil 2004), far less has been done recently to apply Dewey's social and political philosophy, especially his understanding of democracy, substantively to economy. In the early twentieth century pioneers of the institutionalist school of economics, most notably Thorstein Veblen and John Commons (Commons 1934), employed pragmatic methods and insights to offer penetrating analyses and critiques of the mainstream theories of their day, but, although there has been a significant upsurge of interest in institutionalist thinking, it nonetheless remains at the margins of the economic profession.

4 I wish to suggest here that the Mondragon Cooperative Corporation, a network of largely worker cooperatives in the Basque region of Spain, begun in the 1950's, following Spain's Civil War and Francisco Franco's especially brutal treatment of the Basque people for having resisted his rise to power, provides an excellent example of Deweyan economy, although neither Pragmatism generally nor Dewey in particular has influenced the shaping of Mondragon. I will proceed by, first, delineating what I take to be some of the central features of a Deweyan economy and, second, describing some of the intellectual sources and central features of the Mondragon cooperatives, and I will conclude by highlighting the central ways in which Mondragon manifests the sort of economy that I believe Dewey would endorse.

\section{Features of a Deweyan Economy}

\section{I.1. Economic Growth as Human Growth}

Dewey's understanding of "democracy" is fundamentally tied to his notion of "growth": democracy for him is the application of social intelligence and scientific method for the promotion of human growth. "Growth," as he defines it in turn, consists of everincreasing reconstructive possibilities for experience, in terms of its richness, complexity, and integrity: it is primarily qualitative, rather than quantitative. For an economy to be truly democratic and hence healthy, therefore, it must function in service to human growth: it must provide the material means for human growth to occur, and "economic growth" must be based in some such notion of healthy human growth or else it becomes an empty abstraction, disconnected from concrete human experience. As Dewey states, "Growth itself is the only moral 'end"' (1920: 181).

6 Mainstream economics, too, speaks extensively of "growth," but it is almost exclusively a quantitative notion, the quantity of goods produced: any sort of production, as measured by monetary market exchanges, is counted as "growth." The late economist Kenneth Boulding often chastised his profession for its failure to make qualitative distinctions among types of growth. There is, on the one hand, the growth of healthy tissue - bone, muscle, brain - he would note, but on the other hand there are also fat and cancer. Conventional economic accounting methods, such as per capita gross domestic product, employed by capitalists and socialists alike, however, treat all such types of growth the same: no qualitative distinctions are made among those types of production and consumption that promote healthy human growth and those that undermine it. ${ }^{2}$

7 The failure of mainstream economics to make qualitative distinctions among types of growth coincides with its reduction of economic value to what is valued by economic agents, namely, buyers and sellers, in accord with the utilitarian calculus that underlies it: economic goods within the market are considered valuable solely to the extent that 
they are valued by consumers, in accord with the utility they anticipate from the goods' consumption, and producers, in accord with the disutility of their production. Hence, mainstream economists make no distinction between warranted human needs and unwarranted, superfluous wants: both are lumped together as "consumer demand."

Dewey, however, like John Stuart Mill, breaks from Jeremy Bentham's narrow utilitarianism and maintains that intelligent distinctions can be made between what is valuable and what is valued, between what is desirable and what is desired, between legitimate human needs and superfluous, unintelligent wants. Intelligence, for Dewey, transforms the vague, indefinite impulses of the organism into specifiable, focused desires for some definite objects and then deliberates about and mediates the competing desires of the organism according to competing notions of "value" and "good," giving impulses and desires order and greater unity. Intelligence is not merely the slave of desire but an instrument of human growth (Dewey 1922: 132).

9 Furthermore, the subordination of human growth to economic growth is not only manifest in mainstream economic thinking and theorizing, it is existentially felt in the everyday work-lives of many: throughout modern economy workers - high- and low-paid alike - experience themselves as the tools of economic systems and their values of efficient production, as "human capital"; life experiences itself as serving the economic machinery. As Dewey writes, "Instead of the development [growth?] of individualities which [the United States] prophetically put forth, there is the perversion of the whole ideal of individualism to conform to the practices of a pecuniary culture" (Dewey 1930: 49).

Democracy as a way of life, for Dewey, therefore, must entail the building of economic institutions that engender a feeling of the enhanced fullness of life. In this vein Dewey criticized museum and concert hall forms of art that act to compensate for the lack of experienced beauty and joy in everyday work-life. The greatest problem in modern economic thinking, Dewey suggested, lies in its tendency to dichotomize falsely means from ends and thereby to see economic activity as merely a means to other, more desirable or "higher" ends, as drudgery to be endured in order, at the end of the work day, to shop and consume:

No one can possibly estimate how much of the obnoxious materialism and brutality of our economic life is due to the fact that economic ends have been regarded as merely instrumental. When they are recognized to be intrinsic and final in their place as any others, then it will be seen that they are capable of idealization, and that if life is to be worth while, they must acquire ideal and intrinsic value. Esthetic, religious and other "ideal" ends are now thin and meager or else idle and luxurious because of the separation from "instrumental" or economic ends. Only in connection with the latter can they be woven into the texture of daily life and made substantial and pervasive. (Dewey 1920: 178; emphasis in the original)

The development of economic institutions wherein productive economic activity is experienced as manifesting intrinsic, aesthetic value thus goes hand-in-hand with the conceiving of economic growth as serving and as integrated with human growth.

\section{2. Organic, Evolutionary Economics Versus Ideological, Utopian Economics}

Dewey sharply criticizes traditional political theory, from Plato to his present-day, for imagining its task to be conceiving "what the state in general should or must be" (Dewey 
1927: 256-7), designing an ideal, utopian republic, rather than solving practically the messy, concrete problems of everyday public life. His claim is part of the larger criticism that pragmatists level against philosophy generally, namely, that its abstract theorizings have become far too removed from the concrete, existential problems of human life. As William James boldly proclaims, as a fundamental notion of pragmatism, "I do not believe it to be healthy-minded to nurse the notion that ideals are self-sufficient and require no actualization to make us content, [...] ideals ought to aim at the transformation of reality no less!" (James 1907: II, 270). Like Karl Marx, pragmatists hold that philosophy ought to improve the world and not merely describe what it is or even what it ideally ought to be. Or, as Dewey puts it famously in his general call for a "recovery of philosophy": "Philosophy recovers itself when it ceases to be a device for dealing with the problems of philosophers and becomes a method, cultivated by philosophers, for dealing with the problems of men" (Dewey 1917: 46). And he elaborated on how the rigorous application of radically empirical, pragmatic method would bring about such a recovery:

What empirical method exacts of philosophy is two things: First, that refined methods and products be traced back to their origin in primary experience, in all its heterogeneity and fullness; so that the needs and problems out of which they arise and which they have to satisfy be acknowledged. Secondly, that the secondary schools' methods and conclusions be brought back to the things of ordinary experience, in all their coarseness and crudity, for verification. (Dewey 1925: 39)

Clearly economics, especially as once a part of moral philosophy, stands in similar need of recovery. What pragmatism recommends is that economic theory similarly needs to understand itself not in terms of the construction of ideal models, whose austere beauty the ideologue, whether capitalist or communist, first beholds and then aims to impose upon economic life from above, often coercively, but as conceptual tools for the solving of concrete human problems and, as we saw above, the construction of institutions that aid in the cultivation of human growth. Economist Thorstein Veblen, inspired greatly by pragmatism, initiated such a reconstruction of economics by starting his theorizing regarding business civilization and its leisure class, not by imagining what the economy in general should or must be, but by empirically examining and generalizing from the concrete practices of the businessmen of his day - their habits, values, and practices of conspicuous consumption and waste (e.g., Veblen 1899, 1904).

Furthermore, because organisms, and with them their tools, evolve in response to the problems they encounter in their environment, so, too, theories, including economic ones, need to be understood as evolving. Economics is to be conceived as an evolutionary science in a two-fold way: it must understand itself and its theoretical constructs as evolving, and its conceptual tools need to be informed by the latest findings of evolutionary science. Mainstream economics, however, Veblen complains, because it sees its mission, in the Platonic tradition, as one of describing the ideal form of economy, and because it rests so heavily upon pre-Darwinian Newtonian mechanics in constructing its models, is no evolutionary science (Veblen 1898).

\section{3. Empirical, Experimental Science Versus Ideology Posing as "Science"}

Understanding economic concepts and theories, as Dewey understood them, namely, as evolving conceptual tools for solving the concrete problems of living, growing persons, makes the error of economic ideological thinking abundantly clear. By "economic 
ideology" I mean here the mistake of seeing economic concepts and models as fixed, eternal ideals, resembling Platonic forms, that define a priori what a healthy economy must be and to which we must conform our economic behavior and institutions. Like religious fundamentalists, economic ideologues, libertarians and Trotskyites alike, cling tenaciously to their economic models, insisting, in the face of empirical evidence that contradicts their assumptions, that failure always lies in a lack of effort to conform to the model. By contrast Dewey urges economists to use their conceptual tools experimentally and either to modify or to abandon them when empirical evidence indicates that they are failing to solve the public problems that they were intended to solve. He criticizes ideologues of both the right and left, who are willing to allow human beings to starve, suffer, and even die in the name of some pure theoretical ideal, such as the purity of "free markets" or of some sort of communism, thus drawing attacks from both extremes of the political spectrum. Indeed, in criticizing the Marxists of his day Dewey proclaims, "It is ironical that the theory which has made the most display and the greatest pretense of having a scientific foundation should be the one which has violated most systematically every principle of scientific method" (Dewey 1939: 135). More recently Robert Heilbroner offers a powerful critique of how contemporary economic "science" provides a "veil" for the interests of the "regime of capital" and the ideology of free market capitalism (Heilbroner 1988).

Dewey famously exposes numerous false dichotomies of traditional philosophy - subjectobject, nature-culture, fact-value, to name just a few of the more important ones. Similarly, his views of economics transcend the stale false dichotomy of capitalismsocialism. Dewey distinguishes, however, false dichotomies from useful, meaningful distinctions: the terms of deconstructed false dichotomies might still be used meaningfully to designate differing sorts of tools - conceptual, strategic, and institutional - for solving various sorts of economic problems. If the terms, though, cease to be useful in solving our problems and only get in our way, then they are to be jettisoned in favor of more useful ones. "Capitalism" and "socialism," "free markets" and "economic planning," might sometimes be useful in articulating and analyzing economic problems and formulating solutions to them, but when they serve only to divide publics and thereby undermine effective social action, they need to be put aside if not banished from the discussion altogether. In any case, potentially useful economic terms must not solidify into intransient, dichotomous ideologies that claim a priori and without experimental testing, that only certain types of conceptual tools - e.g." "free markets" or "economic planning" - are allowed to solve the economic problems of publics. For Dewey, it matters not whether a proposed solution is "capitalist" or "socialist," but only whether it works or not to solve public problems and promote human growth.

\section{The Mondragon Cooperatives}

17 Worker cooperatives - economic enterprises owned and controlled by those performing the productive labor - are not new and might be dated back to the "reductions" created by the Jesuits in early seventeenth-century Paraguay to help the indigenous peoples of South America protect themselves from the slave trade, and which lasted 160 years (McNaspy 1982, 1984). This model was influenced by St. Thomas More's Utopia. From that work the Jesuits knew already about the brutality of the new economic order that was emerging out of England, through the acts of enclosure, and they looked for alternatives, 
as they sought more immediately to shield the indigenous peoples of Latin America from the slave trade. More, in the same book, offered a vision for such an alternative, but by modern standards it appears authoritarian and even oppressive. Similarly, the Jesuits were paternalistic toward the indigenous peoples in their governance of the reductions, and although there were some measures of democratic participation on the part of those peoples, the reductions were a long way from Deweyan democracy. In these communities, indigenous peoples cooperatively owned and farmed the land. The Jesuits also organized these people in the manufacturing of musical instruments, most of which were exported to Europe. These instruments were among the finest in the world. The reductions also built very impressive structures - churches, roads, fortifications, and schools.

In 1799, British industrialist Robert Owen set about correcting the abuses that came with industrialization and created the first industrial cooperative. He began purchasing, with several partners, a factory at New Lenark and organizing it so that the workers, most of them from the workhouses of the cities, participated in its management and benefited from its profits. Owen believed that persons are largely products of their environment and socialization, and therefore progressive education for workers and their families was central to the New Lenark project. By all accounts it was highly efficient and successful, although Owen severed himself from it in 1828. It operated until 1968, but not as a cooperative. Owen also built, in 1825, a utopian community, New Harmony, in southern Indiana, approximately 200 kilometers from this author's university. This community also achieved sufficient success to demonstrate that worker cooperatives could succeed, but for various reasons, which we will not discuss here, New Harmony eventually failed. Owen shared the view of such diverse thinkers as Aristotle, Thomas Aquinas, Karl Marx, and Amartya Sen, that economy ought to concern itself primarily with fostering excellence in human character and developing people's capabilities - inner goodness rather than with the mere optimizing of utility derived from external goods. Owen's ideas have had lasting influences, especially upon the Mondragon cooperatives in Spain.

Indeed, the worker cooperative communities created by Owen and other utopian socialists, as well as the progressive system of profit-sharing that Edme-Jean Leclaire established in Paris, were sufficiently successful to inspire John Stuart Mill to argue, in his Principles of Political Economy, that cooperatives, owned primarily but not solely by the workers themselves, would be the next phase in the natural evolution of capitalism. Such cooperatives would outperform traditional capitalist firms, Mill argued, because they would be more efficient. As owners of their own businesses, workers work harder; they manage themselves, thereby saving the huge expense of having to employ supervisors; they strive for increased efficiencies and vigilantly work to eliminate waste because they themselves benefit. Furthermore, not being pressured to return maximum profits to investors immediately, such cooperatives could retain fixed portions of profits as reserves and for reinvestment. ${ }^{3}$

More important than their economic advantages, though, cooperatives mark for Mill a significant advancement in the realization of democratic ideals:

The form of association, however, which if mankind continue to improve, must be expected in the end to predominate, is not that which can exist between a capitalist as chief, and work-people without a voice in the management, but the association of the labourers themselves on terms of equality, collectively owning the capital with which they carry on their operations, and working under managers elected and removable by themselves. (Mill 1848: 133) 
21 advance gender equality, a cause for which he and his wife, Harriet Taylor, famously fought: "The same reasons which make it no longer necessary that the poor should depend on the rich, make it equally unnecessary that women should depend on men" (Mill 1848: 125).

So, although the idea of worker cooperatives is centuries-old, the Mondragon cooperatives are the most impressive and successful industrial ones to date. ${ }^{4}$ The parish priest of Mondragon, Father Jose Arizmendiarrieta, led their creation, and Mondragon's success is all the more impressive in light of the devastation and oppression that the Basque people suffered, including the destruction of their ancient capital, Guernica, immortalized by Pablo Picasso's famous painting. Arizmendiarrieta was well educated in economics, sociology, and social/political philosophy, including the works of both Smith and Marx, but the main intellectual influences upon him were Robert Owen and the tradition of Catholic social justice teachings.

Owen's efforts persuaded Arizmendiarrieta that industrial cooperatives could be successful, but equally important Owen's cooperative at New Lenarck warned Arizmendiarrieta against making a huge mistake. In order to raise capital for expansion, in response to its success, the New Lenarck cooperative opened itself to outside investors. Those investors then quickly took over the cooperative and converted it into a traditional capitalist firm, whose chief aim was profit and not social reform and improvement of the conditions of working-class people.

24

alic social justice teachings can be traced all the way back to the early Church, including the writings of Saints Ambrose, Basil, John Chrysostom, Clement of Alexandria, and Augustine - all of whom teach that God gave the goods of the earth to all of humanity in common and against private property (Avila 1983) - and through the works of St. Thomas Aquinas, who justifies limited personal property, following Aristotle's arguments against Plato's communism. ${ }^{5}$ In the modern era, however, Catholic social justice teachings, responding to the ills of the industrial revolution, begin with Pope Leo XIII's 1890 Rerum Novarum, which had an especially profound influence on Arizmendiarrieta (Cheney 1999: 55). In that encyclical Leo XIII criticizes both capitalism and socialism and called for a third option to them. More recently, Pope John Paul II renewed Leo XIII's criticisms and call (John Paul II 1991: Ch. II, 16), and he points to cooperatives, such as Mondragon, as embodiments of Catholic social justice teachings. ${ }^{6}$ For both pontiffs Christianity emphatically affirms the primacy of labor over capital and thus rejects a "rigid capitalism" that places the interests of capital over those of labor. As John Paul II boldly states, the means of production "cannot be possessed against labor, they cannot even be possessed for possession's sake, because the only legitimate title to their possession [...] is that they should serve labor." From the point of view of the Catholic social justice tradition, then, "the position of 'rigid' capitalism continues to remain unacceptable, namely the position that defends the exclusive right to private ownership of the means of production as an untouchable 'dogma' of economic life" (John Paul II 1981: 31-2).

The Mondragon Cooperative Corporation presently employs 85,000 people, manufactures virtually every sort of consumer and capital goods, with annual revenues of almost 15 billion Euros, and commands over 33 billion Euros in total assets (Mondragon 2011). The core of Mondragon is its impressive array of over 300 worker-owned producer

European Journal of Pragmatism and American Philosophy, III-2 | 2011 
cooperatives, but it is supported and enhanced by a number of consumer, agricultural, housing, and "second-degree" cooperatives. Second-degree cooperatives are owned and operated by the other cooperatives as well as their own workers. They include a bank, the Caja Laboral Popular (Working Peoples' Bank), about whose importance we will say more later, a research center, health and social security services, and schools, including a recently opened university.

In recent years Mondragon has established itself as the vanguard of the international cooperative movement, anticipating the United Nations' "Year of the Cooperatives" in 2012. It has created dozens of development offices around the world and has entered into collaborative arrangements with cooperatives outside its region, for example, in France and Italy.

Let us selectively list some central features of the Mondragon cooperatives especially helpful to our analysis here. These features pertain especially to the producer cooperatives but are modified to fit the nature and purposes of the other cooperatives.

1. Workers as owners; owners as workers. For the first half of Mondragon's history every worker was an owner, and every owner was a worker. More recently, however, Mondragon cooperatives are allowed a growing number of contract workers, who are non-owners. Mondragon learned early on that some workers simply do not want to be involved in the responsibilities of cooperative ownership. Moreover, non-owner workers allow the Mondragon cooperatives greater flexibility in times of economic downturn. Over $85 \%$ of Mondragon workers, however, remain co-owners of the cooperatives in which they work.

29 2. Governance. Ultimate power for each cooperative lies in its General Assembly, which meets at least once per year and consists of all the cooperative's members, each having one vote. Attendance averages 70 s\% (Cheney 1999: 58). Member-workers democratically elect a Governing Council and a Social Council, each consisting entirely of worker-owners. The Governing Council is responsible for management of the cooperative and hires and fires managers, who might come from within or be recruited from outside the cooperative. Once elected, managers enjoy considerable control over day-to-day operations. Ultimately, however, they are responsible to the worker-owners, through their Governing Councils, who do not hesitate to dismiss managers who do not perform well. The Social Council is responsible for determining salaries and working conditions, and Cheney reports that the strongest cooperatives in Mondragon are those that maintain the healthiest balances between their Governing and Social Councils (Cheney 1999: 60-1).

30 3. Wage differentials. Wages vary, depending on workers' skill, responsibility, and the difficulty of tasks, but each cooperative within Mondragon establishes what it considers an appropriate fixed ratio between its highest and lowest paid workers. In some cooperatives this ratio is allowed to go as high as 9:1, although none actually do go so high, and the average among the cooperatives is about 4.5:1. By contrast, ratios in major U.S. corporations are often well over 1000:1.

31 4. Distribution of profits. Profits are distributed by a fixed formula. $20 \%$ is retained as reserves. $10 \%$ goes to the community, often to support local schools. The rest are distributed to the workers according to their salaries and length of employment, but workers receive their share of profits only upon leaving the cooperative, thereby preventing any external ownership of the business. Moreover, this arrangement means 
that $90 \%$ of all profits - all but the $10 \%$ given to the community - can be reinvested in the business or held as cushion in hard time. Mondragon cooperatives enjoin an extraordinary rate of reinvestment, not found anywhere among traditional capitalist firms, and it gives Mondragon cooperatives a powerful competitive advantage over other businesses.

5. Cooperation among cooperatives. Cooperation among cooperatives is institutionalized in at least two ways. First, every study of Mondragon confirms that key to its success and what most distinguishes it from other cooperatives throughout the world and in the past, is the role of its bank. The Caja Laboral Popular, as a second-degree cooperative, is owned and operated by the other cooperatives, as well as by its own workers, thereby linking together all the cooperatives into a web of mutual financial support. The primary objective of the bank is not to maximize its profits but to assist the member cooperatives, facilitate new cooperatives, and insure that they all succeed. The system is so good that, in over 50 years, fewer than three percent of Mondragon cooperatives have ceased, many of those not even for financial reasons, compared to new-business failures of $60-80 \%$ in the United States.

Second, and in addition to the bank, Mondragon cooperatives are structurally unified by the Cooperative Congress, begun in 1986. The Congress, with delegates from all of the cooperatives, provides a forum for discussing broad matters of social vision and general policy and "represents the firm consolidation of democratic control," but it has no coercive power (Morrison 1991: 160).

6. Anarchism and the State. A secondary influence on Arizmendiarrieta's creation of Mondragon was the anarcho-sydicalist producer cooperatives in Catalonia, which operated before and through the Spanish Civil War (Cheney 1999: 39). Furthermore, Arizmendiarrieta, despite being a cleric in the highly hierarchical Catholic Church, disliked centralized power and refused any position of formal authority in Mondragon, except as Director of the League for Education and Culture (Morrison 1991: 143). Indeed, some describe Mondragon as an "anarchist" economy because, although its cooperatives do pay taxes to the central government, they operate largely independently of the state, providing their own social security and health care benefits and operating their own schools and university. This anarchist strain in Mondragon, however, is due more to historical circumstances than to anarchist political philosophy. As a result of its civil war and Franco's oppression, the Basque region became increasingly separated from the rest of Spain: it was left to rebuild itself without assistance from the Spanish government, centered in Madrid. Plus, as mentioned already, Franco's oppression intensified Basque nationalism. If Mondragon is "anarchistic," it is mainly because the region grew used to living without the state.

35 7. The place of profit. Because the cooperatives are owned and self-managed by the workers themselves, they measure their performance not by profits but by job creation, quality, and security. Indeed, a central principle of Mondragon is the subordination of capital and profits to labor (in accord with Catholic social principles, as we saw above). Of course cooperatives must be profitable in order to continue, but profit is seen only as a means to securing employment and a better life for workers, not as an end in itself.

8. Environmental stewardship. Mondragon cooperatives are of varying sizes: some consist of only a few workers, while others consist of thousands of workers. Moreover, some involve heavy industry which could pose severe environmental problems to the region. Because local workers own the Mondragon cooperatives, however, they experience 
themselves the consequences of any environmentally irresponsible actions. Thus, they are often viewed as models of environmental stewardship and responsibility and have been recognized as such by European environmentalist groups. Indeed, Morrison describes Mondragon as a model of "ecological postmodernism" and takes its environmental record to be its greatest achievement (Morrison 1991: 4-5). As he notes, a core value of Mondragon is "equilibrio," which manifests itself not just in cooperative human relationships but also in harmony with nature (Morrison 1991: 162-3).

9. Education for democratic cooperative life. From the very beginning education has been at Mondragon's foundation, and 13 years before the creation of its first cooperative, Arizmendiarrieta formed, in 1943, a technical and professional school, which produced much of Mondragon's early leadership. His own philosophy of education was strongly influenced by the work of Paulo Freire: education not only prepares people for productive work, but, more importantly, it provides the means for self-liberation. Like Dewey, Arizmendiarrieta, following Freire, believed that proper education for democratic life must not merely teach the formal principles of democracy but must itself be democratic. So Mondragon has built an impressive set of educational institutions, from pre-schools to a university, democratically operated by teachers, parents, elements of the community, and students. The schools teach not only practical, technical, and professional skills, but also the Basque language and culture, cooperative principles and values, and the philosophy underlying them. Indeed, as partial member-owners, students in the technical school participate in its governance and thereby not only learn about but also practice democracy as a way of life.

Although this description of the Mondragon cooperatives has been brief, how they exemplify the central features of Deweyan economics should be evident. They have attained a level of economic democracy unmatched ever in world history: theirs is not merely a formal political democracy wherein people go to the polls every few years to cast ballots and which can be manipulated too easily by powerful moneyed, antidemocratic interests. Rather, theirs is a democracy that workers practice everyday at their places of work.

Mondragon has effectively institutionalized the intergration of human growth into economic growth through its subordination of capital to labor. As Cheney describes, "Seeing themselves as neither in the service of capital nor alienated from it, the coops aimed to subordinate the maintenance of capital to the interests of labor and human values" (Cheney 1999: 38-9). Labor democratically controls capital and is treated thereby as a fixed rather than a variable cost of production. In times of economic difficulty, such as the present, labor is the absolutely last expense to be cut, and even then workers will be transferred to another cooperative or sent to the technical school or university for retraining rather than laid off altogether. As we saw Mondragon derived this principle of the subordination of capital to labor from Catholic social teaching, and Arizmendiarrieta considered it a matter of social justice: "Cooperation is an authentic integration of the person in the economic and social process, and it is central to a new social order; employees working cooperatively ought to unite around this ultimate objective, along with all who hunger and thirst for justice in this world of work" (as quoted and translated by Cheney 1999: 39). Mondragon measures economic growth not by the shear quantity of goods produced and consumed but on the basis of the cooperatives' ability to provide stable employment in accord with human dignity. Profit is treated not as the purpose of business but as a means to create the conditions for dignified human living. As Cheney 
describes, "the growth of the cooperatives ... has meant far more than 'adding more of the same' to existing structures," but has included the personal growth of members as well as the strengthening of relationships among themselves, with the community, and even with the world and the capacity of the enterprise to adapt to a changing global economic environment (Cheney 1999: 74).

Mondragon emerged in response to the colossal concrete problem of a devastated Basque region, and its focus has remained improving the quality of life of its people, not profit maximization or rigid conformity to any utopian ideal. It has certain guiding ideals and principles, but these are continuously rethought in light of changing conditions. Mondragon has remained experimental, as a slogan often repeated there indicates: "We build the road as we travel." This is economic pragmatism at its best. Indeed, both Morrison and especially Cheney examine how Mondragon has experimentally evolved and grown in response to increasing encounters with global market forces and pressures that challenge its democratic commitments.

Mondragon's capacity to change and evolve is seen in two specific examples. First, Mondragon began committed to the ideal of every worker being an owner. It discovered, however, that not every worker wanted the responsibility of ownership. In addition, Mondragon learned that there is a trade-off between economic growth, which provides more jobs for people, on the one hand, and job security, on the other. It thus tries to strike a balance between these two desirable but conflicting aims and allows member cooperatives to hire certain percentages of non-owner workers (Cheney 1999: 77).

A second example involves the ratio of highest paid to lowest paid workers. At its start Mondragon enforced a 3:1 ratio. This was increased to 4.5:1, especially to attract topquality physicians as it established its system of universal health-care. It was increased again to 6:1, and now each cooperative is allowed to establish its own ratio. Some cooperatives allow for a ratio as high as 9:1, although none practice it, and the average is 4.5:1.

In these and other instances Mondragon has been criticized by some for forsaking its principles in order to grow and by others for not compromising more in order to promote even more growth. Indeed, in 1991 a group of four cooperatives - later five - broke away from the Mondragon Cooperative Corporation to create the ULMA group because its members believed that the MCC had drifted too far away from its founding principles, especially with respect to salary, in its pursuit of growth. ULMA continues, however, to cooperate closely with MCC on many matters, including the building of Mondragon University, and to belong to Caja Laboral Popular (Cheney 1999: 85). Some, too, have expressed concerns, both on the left and, surprisingly, from the Catholic Church, that a managerial elite has arisen. I, along with many within Mondragon, simply do not see this because ultimately management is responsible to the democratically expressed interests and desires of the worker-owners: effective mechanisms are in place to insure this responsibility (Cheney 1999: 44).

44 I see Mondragon's flexibility and willingness to adapt in the face of changing economic realities as one of its strengths rather than a weakness, and I believe Dewey would agree. Principles, like all concepts, ought to function in the service of human growth, not as the a priori definition of growth: the quality of concrete human experience, not adherence to principles, is the proper measure of growth. Throughout all its adaptations and changes, Mondragon has held true to an understanding of "growth" and "democracy" that is both grounded in experience and comprehensive. 
So, are cooperatives such as Mondragon capitalistic or socialistic? Or, are they a third type of economic system? Does it matter? The answer to such questions depends on how one defines "capitalism" and "socialism."

"Capitalism" is defined traditionally, including by Marx, as a system of private ownership of capital, or the means of production, and "socialism" is defined as a system of collective ownership of capital, for example, by the state. If we define "capitalism" and "socialism" in these ways, then the Mondragon cooperatives are capitalist enterprises (as Mill envisioned worker cooperatives) because they are restrictively owned by the workers and not by the society generally or the state. They might be termed a system of "worker capitalism" because the workers are the capitalists. Partially for this reason cooperatives were strongly criticized by Marx and his followers (Morrison 1991: 151). Indeed, the most critical study of Mondragon was authored by a Marxist (Kasmir 1996).

If, however, we define "capitalism" as either a system that privileges the interests of capitalists, over those of workers, or as a system in which capital hires labor, then cooperatives are not capitalistic. In cooperatives capital serves labor; labor owns and controls capital. Cooperatives measure themselves by what they do for the workers who own them. Do they provide secure employment and serve the workers' well-being? To do these things well, of course they must be profitable, but the making of profit, as we noted with respect to Mondragon, is not the end or purpose of the cooperative: profit is but a means for serving the growth of workers, both quantitatively and qualitatively.

So, because cooperatives such as Mondragon do not clearly fit the definition of either "capitalism" or "socialism," I believe that they are best understood as a genuinely third option, transcending the false capitalism-socialism dichotomy. If only for that reason, they are valuable to study because they help to free our imaginations to envision possibilities for economy beyond the stale capitalist-socialist debate. Far more important, though, than the label we might choose to describe cooperatives, like Mondragon, is what they might teach us about how to create a better, healthier, more just world, for ourselves and for generations to come.

Indeed, Mondragon is an economic model that many defenders of both "capitalism" and "socialism" might embrace if they can see beyond those ideological terms. Socialists and liberal progressives often see Mondragon as effectively achieving workplace democracy and overcoming the exploitation and alienation that they associate with capitalism. Overall and contrary to criticisms mentioned above, there are few perceived classdistinctions in Mondragon: Mondragon has done more to obliterate class distinctions and hierarchies than any other industrialized society of which I am aware, although such is not an expressed goal of Mondragon as it is of Marxists, and it has created a society in which there is a strong sense of solidarity among all the people in creating a better life for everyone - for themselves, for their children, and for generations to come. On the other hand, Mondragon has appeal to defenders of free market capitalism because, first, it maintains restricted ownership of capital: capital is not state-owned but held by limited, identifiable groups of workers. Mondragon cooperatives avoid competing among themselves, but they do allow markets to set prices. Furthermore, although there is a degree of centralized planning, it is through the bank and not the state, and as indicated above, Mondragon operates largely independently of the state. That it transcends the traditional, false socialist-capitalist dichotomy and thereby is able to bring together those on both sides of that divide in an expanded sense of a "public" (in Dewey's sense), is one of Mondragon's most important significances. 
50 As the Dewey-inspired institutionalists maintained, though, economies must always be studied and understood within the larger contexts of their cultures. Therefore, I do not think, nor would Dewey, that one can simply abstract the Mondragon model from the Basque culture and history out of which it grew. For example, due to the oppression that the Basque people experienced, they enjoy a high degree of heart-felt solidarity, which few if any industrial nations enjoy. Furthermore, they have one of the oldest traditions of democracy in the world, stretching back to medieval times. They take as self-evident that people have a right to participate in the governance of the institutions that affect their lives. Such a unique history and tradition contribute significantly to Mondragon's success. I do think, however, that we can learn much from Mondragon: Mondragon inspires us to create a better world for ourselves and for our children, and the study of it frees our imaginations to think about possibilities for economy that conventional economic theories, especially those designed to defend the structures of capitalism and the interests of capitalists, do not allow us to consider. Moreover, for those of us inspired by Dewey's social and political philosophy, it helps us to imagine the sort of economy Dewey might have helped to create.

\section{BIBLIOGRAPHY}

AVILA C., (1983), Ownership: Early Christian Teaching, Maryknoll, Orbis Books.

BYERS D. M. (ed.), (1985), Justice in the Marketplace: Collected Statements of the Vatican and the U.S. Catholic Bishops on Economic Policy, 1891-1984, Washington, United States Catholic Conference.

CHENEY G., (1999), Values at Work: Employee Participation Meets Market Pressure, Updated Edition, Ithaca, NY, ILR Press.

COMmons J. R., (1934), Institutional Economics: Its Place in Political Economy, Madison, University of Wisconsin Press, 1961.

DEWEY J., (1917), “The Need for a Recovery of Philosophy," in The Middle Works, 1899-1924 (MW), ed. Jo Ann Boydston, Vol. 10, Carbondale, Southern Illinois University Press, 1980.

DEWEY J., (1920), Reconstruction in Philosophy, in MW, Vol. 12, 1982.

DEWEY J., (1922), Human Nature and Conduct, in MW, Vol. 14, 1983.

DEWEY J., (1925), Experience and Nature, in The Later Works, 1925-1953 (LW), ed. Jo Ann Boydston, Vol. 1, Carbondale, Southern Illinois University Press, 1981

DEWEY J., (1927), The Public and Its Problems: An Essay in Political Inquiry, in LW, Vol. 2, 1984.

DEWEY J., (1930), Individualism Old and New, in LW, Vol. 5, 1984.

DEWEY J., (1939), Freedom and Culture, in LW, Vol. 13, 1988.

HEILBRONER R., (1988), Behind the Veil of Economics: Essays in the Worldly Philosophy, New York, W. W. Norton. 
JAMES W., (1907), Letter to Charles A. Strong, April 9, 1907, in The Letters of William James, ed. Henry James, 2 vols., Boston, Atlantic Monthly Press, 1920.

JOHN PAUL II, (1981), On Human Work: Laborem Exercens, Washington, United States Catholic Conference.

JOHN PAUL II, (1991), On the Hundredth Anniversary of Rerum Novarum: Centesimus Annus, Encyclical Letter, Washington, United States Catholic Conference.

KHALIL E. L., (ed.), (2004), Dewey, Pragmatism, and Economic Methodology, London, Routledge.

KASMIR S., (1996), The Myth of Mondragon: Cooperatives, Politics, and Working-Class Life in a Basque Town, Albany, State University of New York Press.

MCNASPY C. J., S.J., (1982), Lost Cities of Paraguay: Art and Architecture of the Jesuit Reductions, 1607-1767 , Chicago, Loyola University Press.

MCNASPY C. J., S.J., (1984), Conquistador Without Sword: The Life of Roque Gonzalez, S. J., Chicago, Loyola University Press.

MILL J. S., (1848), Principles of Political Economy, with Some of Their Applications to Social Philosophy, ed. Donald Winch, Middlesex, England, Penguin, 1970.

MONDRAGON COOPERATIVE CORPORATION (2011), Yearly Report 2010, [mondragon-corporation.com/ language/en-US/ENG/Economic-Data/Yearly-Report.aspx], accessed 28 October 2011.

MORRISON R., (1991), We Build the Road as We Travel: Mondragon, a Cooperative Social System, Philadelphia, New Society.

OWEN R., (1970), A New View of Society and Report to the County of Lenark, ed. V. A. C. Gatrell, Middlesex, England, Penguin.

VEBLEN T., (1898), “Why is Economics Not an Evolutionary Science?,” The Quarterly Journal of Economics 12

VEBLEN T., (1899), The Theory of the Leisure Class: An Economic Study in the Evolution of Institutions, New York, The Macmillan Company.

VEBLEN T., (1904), Theory of Business Enterprise, New York, C. Scribner's Sons.

WHYTE W. F. et al., (1983), Worker Participation and Ownership: Cooperative Strategies for Strengthening Local Economies, Ithaca, ILR Pres.

\section{NOTES}

1. "From the standpoint of the individual, [democracy] consists in having a responsible share according to capacity in forming and directing the activities of the groups in which one belongs and in participating according to need in the values which the group sustains" (Dewey 1927: 327-8).

2. Morrison makes a similar point (1991: 136-9).

3. Mill, "On the Probable Futurity of the Labouring Classes" (1848: 118-42).

4. Although much of its factual information is dated Morrison (1991) remains one of the best analyses of Mondragon and especially the philosophy underlying it.

5. Thomas Aquinas, Summa Theologia, 2nd Pt. of 2nd Pt., Ques. 66, Art. 2.

6. E.g., "Address at Newfoundland," September 12, 1984 (in Byers 1985: 361). 


\section{ABSTRACTS}

This article argues that the Mondragon cooperatives, a network of worker-owned businesses in the Basque region of Spain, offers a concrete example of Deweyan economy, wherein democracy is part of everyday work-life. It first identifies three central features of Deweyan economy: a) its notion of economic growth is rooted in human growth; b) it is organic and evolutionary, not ideological or utopian; and c) it is empirical and experimental. Second, the article sketches some of the important historical and philosophical influences upon and distinct features of the Mondragon cooperatives, and, third, it indicates how the Mondragon cooperatives manifest each of the three central features of Deweyan economy. The article concludes by suggesting that the Mondragon cooperatives have achieved a previously unknown level of economic democracy and that its recent modifications in response to changing economic conditions, far from being retreats from fundamental principles, as some critics maintain, are evidence of Mondragon's experimental, non-ideological character. Furthermore, it is an economic model that transcends the stale, false capitalist-socialist dichotomy and thereby helps us to imagine creative solutions to current economic problems.

\section{AUTHOR}

KENNETH W. STIKKERS

Southern Illinois University

kstikker[at]siu.edu 